\title{
Spatio-temporal variability of atmospheric impurities over Lake Baikal during the expeditions to the SRV “V.A. Koptyug" in 2019
}

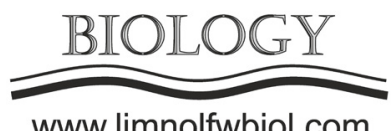

www.limnolfwbiol.com

\author{
Zhamsueva G.S. * Zayakhanov A.S., Tsydypov V.V., Balzhanov T.S., \\ Dementeva A.L., Starikov A.V., Sungrapova I.P.
}

Institute of Physical Materials Science, Siberian Branch of the Russian Academy of Sciences, Sakhyanovoi Str., 6, Ulan-Ude, 670047, Russia

\begin{abstract}
Route observations were carried out aboard the SRV “Akademik V.A. Koptyug” on study of the spatio-temporal variability of small gas imp $\mathrm{riti}_{\mathrm{e}} \mathrm{s}\left(\mathrm{O}_{3}, \mathrm{NO} 2, \mathrm{SO} 2\right)$ at Lake Baikal. The spatiotemporal variablity of $\mathrm{O}_{3}, \mathrm{NO} 2, \mathrm{SO} 2$ is extremely heterogeneous over the lake. Under conditions of the formation of a stable air mass in the warm sector of cyclone, high daytime air temperatures and elevated concentrations of surface ozone up to $120 \mu \mathrm{g} / \mathrm{m} 3$, sulfur dioxide (up to $30 \mu \mathrm{g} / \mathrm{m} 3$ ) were observed. The concentrations of nitrogen oxid $_{e}$ (NO, NO2) did not exceed the background values. It is shown that in the water area of the lake the content of nitrogen dioxide is much lower than that of sulfur dioxide. A comparative analysis of the results of measurements of small gas imp riti $_{\mathrm{e}} \mathrm{SO} 2$, NO2 over the water area of the lake and at the coastal station showed that with long-distance transport of anthropogenic impurities, gaseous nitrogen oxides usually transform into nitrates due to a higher ate of NO2 oxidati $n$ than SO2.
\end{abstract}

Keywords: Small gas impurities, atmosphere, smoke aerosol, gas analyzers, Lake Baikal

Experimental studies of small gas impurities in the drive layer of the atmosphere of Lake Baikal was conducted from July 24 to August 4, 2019 aboard the SRV “Akademik V.A. Koptyug” using chemiluminescent gas analyzers.

Pure shows the experimental data of spatiotemporal distribution of concentration ozone, sulfur dioxide, nitrogen oxides, meteorological parameters along the ship's route at Lake Baikal. The spatio-temporal variability of $\mathrm{O}_{3}$ and small gas impurities $\left(\mathrm{NO}_{2}, \mathrm{SO}_{2}\right)$ is extremely heterogeneous over the lake.

During the measurement period from July 24 to 29 , the area of measurements ship at the south-west of Baikal water area was influenced by a low-gradient low pressure baric field. Under conditions of the formation of a stable air mass in the warm sector of cyclone, high daytime air temperatures and elevated concentrations of surface ozone up to $120 \mu \mathrm{g} / \mathrm{m}^{3}$, sulfur dioxide (up to 30 $\mu \mathrm{g} / \mathrm{m}^{3}$ ) were observed. The concentrations of nitrogen oxides $\left(\mathrm{NO}, \mathrm{NO}_{2}\right.$ ) did not exceed the background values. An analysis of backwards trajectories calculated according to the HYSPLIT model showed that air mass was drifted from the territories of large settlements and industrial centers of the Republic of Buryatia, such as Ulan-Ude, Gusinoozersk, Kamensk, Selenginsk,
Kabansk, etc. One of the major sources of sulfur dioxide emissions is the Selenginsky pulp and cardboard mill, where the production of unbleached sulfate pulp is accompanied by emissions of both basic and specific pollutants containing sulfur (dimethyl sulfide, methyl mercaptan, sodium sulfate, carbon disulfide).

Despite the observed high concentrations of $\mathrm{SO}_{2}$ along the Listvyanka-Olkhon route, the concentrations of nitrogen oxides $\left(\mathrm{NO}, \mathrm{NO}_{2}\right.$ ) remained at the level of background values (3-7 $\mu \mathrm{g} / \mathrm{m}^{3}$ ) (Fig.), although usually their concentrations increase synchronously with $\mathrm{SO}_{2}$ concentrations. It is known that gaseous nitrogen oxides usually transform into nitrates faster than sulfur dioxide (Cocks et al., 1983), the rate of $\mathrm{NO}_{2}$ oxidation is 5 times higher than that of $\mathrm{SO}_{2}$. Therefore, the absence of nitrogen dioxide at high concentrations of $\mathrm{SO}_{2}$ may mean that, possibly, the detected plume of $\mathrm{SO}_{2}$ pollution near the southwestern coast accumulated for quite a long time (up to several hours) and gaseous nitrogen oxides managed to oxidize to nitrates. In conditions of long-distance transport of anthropogenic gases during ship measurements over the lake, this was not observed. Due to the higher rate of $\mathrm{NO}_{2}$ oxidation compared to $\mathrm{SO}_{2}$, lower concentrations of nitrogen oxides or their complete absence are recorded (Fig.). Similar results were noted in (Obolkin et al., 2017) during the period 

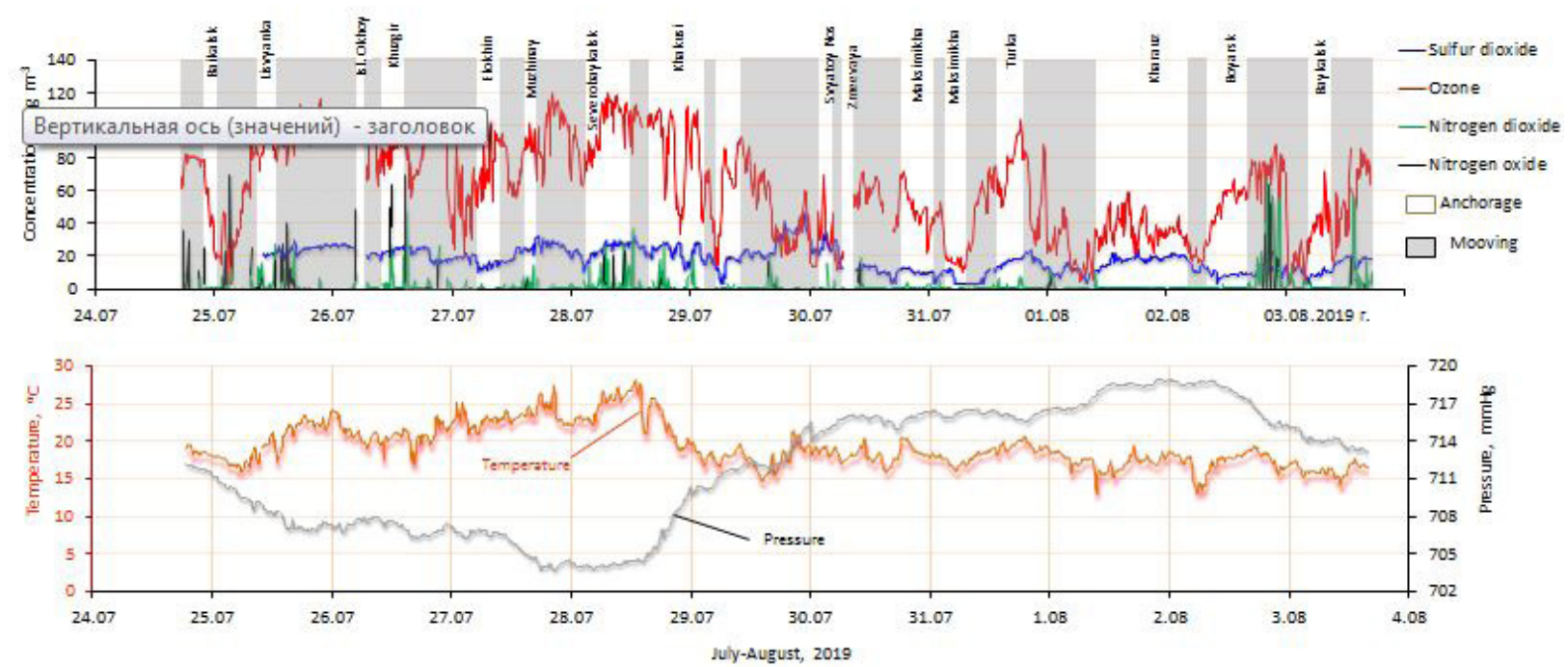

Fig. The time course of the concentration of surface ozone, nitrogen dioxide and sulfur dioxide, temperature, pressure along the entire route of the SRV "Akademik V.A. Koptyug”

of experiments on Lake Baikal.

This work was carried out with financial support in the framework of state assignment No. 03362019-0007 and with partial support from the Russian Foundation for Basic Research No. 17-29-05044-ofi-m in terms of data processing.

\section{References}

Cocks A.T., Kallend A.S., Marsh A.R.W. 1983. Dispersion limitations of oxidation in power plant plumes during longrange transport. Nature 305: 122 123. DOI: $10.1038 / 305122 \mathrm{a} 0$

Obolkin V.A., Potemkin V.L., Makukhin V.L. et al. 2017. Long-distance transport of atmospheric emissions plumes from regional coal-fired power plants to the South Baikal. Optika Atmosfery i Okeana [Atmospheric and Oceanic Optics] 30: 60-65. (in Russian) 